\title{
KUALITAS INSTRUMEN PENILAIAN HASIL BELAJAR SUMATIF SENI RUPA DI SMP KABUPATEN SLEMAN
}

\author{
Bambang Prihadi*, Trie Hartiti Retnowati, Dwi Wulandari \\ Fakultas Bahasa dan Seni, Universitas Negeri Yogyakarta \\ *E-mail: bambangpri@uny.ac.id
}

\begin{abstract}
Abstrak
Penelitian ini merupakan penelitian deskriptif kuantitatif untuk menjelaskan pelaksanaan dan kualitas instrumen penilaian sumatif oleh satuan pendidikan yang berfokus pada penilaian aspek kognitif. Sampel dipilih melalui teknik random sampling. Data penelitian adalah data pelaksanaan dan instrumen penilaian hasil belajar sumatif mata pelajaran Seni Budaya aspek Seni Rupa di SMP Kabupaten Sleman berupa tes objektif dari kegiatan Penilaian Tengah Semester (PTS), Penilaian Akhir Semester (PAS) dan Penilaian Akhir Tahun (PAT) pada tahun 2019-2020. Analisis data dilakukan dengan menggunakan analisis statistika deskriptif. Hasil penelitian menunjukkan bahwa pelaksanaan penilaian sumatif dilaksanakan oleh para guru Seni Budaya sesuai dengan acuan-acuan pelaksanaan Kurikulum 2013 yang disesuaikan dengan kebijakan sekolah. Instrumen utama penilaian sumatif tersebut berupa soal pilihan ganda dengan empat pilihan jawaban. Secara umum kualitas soal tersebut sangat baik dari segi materi, konstruksi, dan bahasa. Dari segi tingkat kesukaran, secara umum instrumen penilaian tersebut masih didominasi soal dengan tingkat kesukaran mudah dan sedang dan dari segi tingkat pengetahuan masih didominasi soal dalam kategori tingkat ingatan dan pemahaman dan belum mencakup soal untuk kategori high order thinking skill.
\end{abstract}

Kata Kunci: kualitas instrumen, penilaian sumatif, seni rupa, SMP kabupaten Sleman

\section{THE QUALITY OF INSTRUMENTS OF ART LEARNING SUMATIVE ASSESS- MENT IN SLEMAN JUNIOR HIGH SCHOOLS}

\begin{abstract}
This research is a quantitative descriptive study to explain the implementation and quality of summative assessment instruments by educational units that focus on assessing cognitive aspects. The sample was selected by random sampling technique. The research data is the implementation and the assessment instruments for summative learning outcomes in the arts and cultural subject focusing on art aspect in junior high schools of Sleman Regency in the form of objective tests of Mid-Semester Assessment (PTS), Final Semester Assessment (PAS) and Year-End Assessment (PAT) in 2019-2020. Data were analyzed using descriptive statistical analysis. The results showed that Cultural Arts teachers carried out the implementation of summative assessment in accordance with the guidelines for implementing the 2013 Curriculum, which was adjusted to school. The main instrument for summative assessment is multiple-choice questions with four answer choices. In general, the quality of the questions was very good in terms of material, construction, and language. In terms of the level of difficulty, in general, the assessment instrument is still dominated by questions with easy and moderate difficulty levels, and very little covers difficult ques-
\end{abstract}


tions. In terms of the level of knowledge, it is still dominated by questions in the category of memory and understanding levels. It does not include questions for the high-order thinking skill category.

Keywords: instrument quality, summative assessment, art learning.

\section{PENDAHULUAN}

Sebagai salah satu bagian penting dalam pelaksanaan pembelajaran di sekolah, penilaian berfungsi untuk memetakan tingkat keberhasilan, kualitas dan produktivitas kegiatan pembelajaran sekaligus sebagai dasar perbaikan proses pembelajaran selanjutnya. Penilaian atau evaluasi pembelajaran dilakukan melalui pengumpulan data baik melalui teknik tes maupun non tes dan analisis data hingga diperoleh gambaran tentang ketercapaian hasil belajar secara akurat (Suharsimi, 2009; Santoyo dkk, 2019). Dalam pelaksanaannya, diperlukan alat ukur yang baik agar menghasilkan penilaian terpercaya dan akurat, yang dapat menggambarkan keadaan sebenarnya dari objek yang diukur. Dalam teknik tes diperlukan instrumen tes yang berkualitas dan tidak bias agar hasil penilaian bisa diterima oleh semua pihak dan tidak merugikan pihak tertentu (Widyaningsih \& Yusuf, 2018).

Kementerian Pendidikan dan Kebudayaan telah memberikan pedoman penyusunan instrumen penilaian melalui Panduan Penilaian oleh Pendidik dan Satuan Pendidikan yang bisa diakses oleh seluruh guru dan sekolah untuk dijadikan sebagai acuan dalam penyusunan instrumen penilaian (Kemendikbud, 2017). Meski begitu, penerapannya di lapangan, khususnya di kabupaten Sleman, masih menemui kendala. Analisis kualitas instrumen yang seharusnya menjadi bagian dari pelaksanaan penilaian belum dilakukan dengan optimal, sehingga instrumen penilaian yang ada belum diketahui kualitasnya. Karena itu, analisis terhadap kualitas instrumen penilaian masih sangat diperlukan. Penelitian ini bertujuan menganalisis kualitas instrumen sebagai masukan perbaikan dalam pembuatan instrumen penilaian selanjutnya. Kualitas instrumen yang dimaksud dalam penelitian ini meliputi segi substansi, konstruksi, bahasa, dan validitas empirisnya.

Penilaian yang ada di tingkat Sekolah Menengah Pertama (SMP) terdiri dari Penilaian Harian $(\mathrm{PH})$, Penilaian Tengah Semester (PTS), Penilaian Akhir Semester (PAS), Penilaian Akhir Tahun (PAT), dan Ujian Sekolah (US). Penelitian ini berfokus untuk menganalisis instrumen penilaian pada PTS, PAS, dan PAT karena keduanya merupakan bentuk evaluasi esensial dalam penyelenggaran pendidikan di sekolah. Penilaian Akhir Semester (PAS) dan Penilaian Akhir Tahun (PAT) bersifat sumatif dimana PTS berfungsi menggambarkan kualitas ketercapaian KD hingga pekan ke 8-9, PAS berfungsi untuk memetakan kualitas hasil belajar pada semester gasal dengan materi semua KD pada semester tersebut, sedangkan PAT berfungsi untuk menggambarkan kualitas hasil belajar pada semester genap dengan materi semua KD pada semester genap. PTS, PAS dan PAT tergolong ke dalam penilaian oleh satuan pendidikan yang menggunakan instrumen tes objektif untuk mengukur aspek kognitif siswa dimana soal tesnya dibuat oleh guru yang terhimpun dalam MGMP.

Di tingkat Sekolah Menengah Pertama (SMP), pembelajaran Seni Rupa merupakan bagian dari mata pelajaran Seni Budaya. Sebagaimana mata pelajaran yang lain, pembelajaran seni rupa dalam Kurikulum 2013 mencakup kompetensi inti (KI) dan Kompetensi Dasar (KD) pengetahuan maupun keterampilan (Kemendikbud, 2016). Penelitian ini berfokus menganalisis instrumen yang mengu- 
kur capaian KI dan KD pengetahuan. Karena karakteristik mata pelajaran seni rupa yang berbasis praktik dan berorientasi estetika, penelitian analisis maupun pengembangan instrumen yang telah dilakukan selama ini banyak yang hanya berfokus pada aspek keterampilan yaitu penilaian produk dan proses. Berdasarkan hal tersebut di atas, penelitian ini menganalisis pelaksanaan penilaian dan kualitas instrumen penilaian hasil belajar sumatif mata pelajaran Seni Budaya aspek Seni Rupa di SMP kabupaten Sleman.

\section{METODE}

Penelitian ini menggunakan jenis penelitian deskriptif kuantitatif. Penelitian deskriptif merupakan penelitian yang dilakukan untuk mengetahui nilai variabel secara mandiri, baik satu variabel atau lebih, melalui data atau sampel, tanpa membuat perbandingan atau menghubungkan dengan variabel yang lain (Sugiyono, 2012:29). Subyek penelitian yang dipilih melalui teknik random sampling adalah 13 guru Seni Rupa SMP di Kabupaten Sleman yang merupakan anggota MGMP Seni Budaya Kabupaten Sleman. Dari ketigabelas guru Seni Rupa tersebut, 6 orang mengajar Seni Rupa di kelas VII semester 1, 9 orang mengajar di kelas VII semester 2, 6 orang mengajar di kelas VIII semester 1, 9 orang mengajar kelas VIII semester 2, 6 orang mengajar kelas IX semester 1 dan 11 orang mengajar kelas IX semester 2 .

Pengumpulan data penelitian ini dilaksanakan selama tiga bulan yakni bulan Agustus sampai dengan Oktober 2020. Data penelitian ini terdiri atas dua aspek yaitu aspek pelaksanaan penilaian hasil belajar sumatif hasil belajar seni rupa dan aspek kualitas soal pilihan ganda yang dibuat oleh guru. Data tentang pelaksanaan penilaian hasil belajar sumatif hasil belajar seni rupa dikumpulkan melalui kuesioner untuk diisi oleh responden. Melalui kuesioner tersebut dapat diperoleh data tentang landasan, pertimbangan, serta praktik yang dilakukan oleh guru dalam melaksanakan penilaian hasil belajar tersebut. Kuesioner terdiri atas 6 butir yang meliputi 67 butir pertanyaan. Penyebaran dan pengisian kuesioner tersebut dilakukan secara online melalui Google Form. Untuk melengkapi informasi tentang pelaksanaan penilaian sumatif tersebut, juga digunakan metode wawancara dengan ketua dan anggota MGMP Seni Budaya SMP di Kabupaten Sleman.

Pengumpulan data untuk aspek kualitas soal tes pilihan ganda, digunakan metode dokumentasi, dengan meminta contoh soal tes sumatif pilihan ganda yang dibuat oleh guru dalam dua semester terakhir. Sesuai dengan keadaan pengelolaan dokumentasi soal oleh guru, dapat diperoleh soal pilihan ganda 597 butir soal dari baik berupa soal penialaian tengah semester (PTS), penilaian akhir semester (PAS), maupun penilaian akhir tahun (PAT). Perangkat soal yang dibuat oleh guru bervariasi dari segi jumlahnya, berkisar dari 10 - 50 butir, sesuai dengan kebijakan pengelolaan penilaian penilaian sumatif di sekolah.

Data kualitas soal dihasilkan dengan melakukan analisis kualitatif terhadap sampel soal pilihan ganda yang terdiri atas $60 \mathrm{bu}-$ tir. Analisis ini dilakukan secara inter-rater yang melibatkan tiga penilai yang terdiri atas dua mahasiswa semester ke-4 S2 Program Studi Pendidikan Seni yang berlatar belakang S1 Program Studi Pendidikan Seni Rupa atau S1 Pendidikan Kriya. Penilai yang sebelumnya telah dilatih, melakukan penilaian dengan membaca, memahami, dan menganalisis setiap butir soal dengan menggunakan instrumen daftar cek yang telah disiapkan. Data pelaksanaan penilaian hasil belajar sumatif dan data kualitas soal pilihan ganda tersebut selanjutnya dianalisis dengan menggunakan statistika deskriptif yaknik dengan persentase, dengan kriteria interpretasi sebabagai berikut. 
Tabel 1. Kriteria Interpretasi Penilaian Kualitas Soal

\begin{tabular}{ll}
\hline Rentang Nilai & Kriteria \\
\hline $81 \%-100 \%$ & Sangat Baik \\
$61 \%-80 \%$ & Baik \\
$41 \%-60 \%$ & Kurang Baik \\
$1-10 \%$ & Tidak Baik \\
\hline
\end{tabular}

\section{HASIL DAN PEMBAHASAN}

Hasil

\section{Acuan Penilaian Hasil Belajar}

Dari hasil angket yang dilakukan terhadap responden, diketahui bahwa dalam menyusun soal penilaian tengah semester (PTS), penilaian Tengah Semester (PAS), dan penilaian akhir tahun (PAT), seluruh responden mengacu pada Permendikbud Nomor 23 Tahun 2006, Panduan Penilaian oleh Pendidik dan Satuan Pendidikan SMP 2017, dan Permendikbud Nomor 3 Tahun 2017.

\section{Penilaian Sumatif}

Seluruh responden melakukan PTS pada pekan ke-8 atau ke-9 dan melaksanakan PAS dengan cakupan materi semua Kompetensi Dasar (KD). Dari ketiga-belas responden, hanya satu orang responden yang tidak melaksanakan PTS dengan cakupan KD dari pekan ke-1 sampai ke- 7/8 dan 1 orang responden yang tidak melaksanakan PAS dengan cakupan materi semua Kompetensi Dasar (KD) pada semester II atau genap.

\section{Kriteria Ketuntasan Minimal (KKM) \\ Dalam Dalam melaksanakan penilaian} hasil belajar Seni Rupa, masing-masing responden cenderung memutuskan KKM berdasarkan beberapa alasan. Dari kuesioner yang telah dilakukan, diperoleh data sebagai berikut. Sebagian besar responden yang menggunakan KKM yang sama untuk setiap KD. Hanya $46 \%$ responden menggunakan KKM yang sama untuk setiap KD, sementara 54\% tidak. Alasan yang melatar-belakangi keputusan ini antara lain karena guru menyesuaikan karakteristik, tingkat kompetensi dan tingkat kesulitan setiap KD/materi; menyesuaikan intake, kompleksitas dan daya dukung $\mathrm{KD} /$ materi; memudahkan sosialisasi standar nilai; dan mengikuti keputusan sekolah/kurikulum.

Sebagian besar responden yaitu sebanyak $62 \%$ responden menggunakan KKM yang sama untuk kompetensi dasar pengetahuan (KD 3). Sedangkan 31\% lainnya tidak menggunakan KKM yang sama untuk kompetensi dasar pengetahuan (KD 3). Keputusan ini berdasarkan beberapa alasan, yaitu menyesuaikan tingkat kesulitan materi; menyesuaikan intake, kompleksitas dan daya dukung KD pengetahuan; dan mengikuti keputusan sekolah/kurikulum.

\section{Penilaian Pengetahuan}

Dalam penilaian sumatif para guru Seni Budaya mengembangkan soal berdasarkan cakupan jenis-jenis pengetahuan faktual, konseptual, prosedural, dan metakognitif secara bervariasi.

\section{Analisis Kualitas Soal}

Dalam penelitian ini, analisis kualitas terhadap sampel soal-soal pilihan ganda yang dibuat guru mencakup lima aspek atau unsur, yaitu materi, konstruksi, bahasa, tingkat pengetahuan dan tingkat kesulitan yang dapat diuraikan sebagai berikut.

a. Kualitas Soal dari Aspek Materi

Analisis dari segi materi di sini meliputi tuga kriteria: (1) Pilihan jawaban homogen dan logis, (2) Soal mempunyai satu jawaban yang benar atau paling benar, dan (3) Pokok soal dirumuskan secara jelas dan logis. Rangkuman hasil analisis kualitas soal dari segi materi dapat dilihat pada Tabel 2 . 
Tabel 2. Hasil Analisis Soal dari Aspek Materi

\begin{tabular}{clrrl}
\hline No. & Kriteria & Jumlah & Persentase & \multicolumn{1}{c}{ Nilai } \\
\hline 1 & Pilihan jawaban homogen dan logis. & 46 & $76,67 \%$ & Baik \\
2 & Soal mempunyai satu jawaban yang benar/ paling benar. & 50 & $83,33 \%$ & Sangat Baik \\
3 & Pokok soal dirumuskan secara jelas dan tegas. & 51 & $85,00 \%$ & Sangat Baik \\
\hline \multicolumn{2}{c}{ Jumlah } & & $245 \%$ & \\
& Rata-Rata & & $(81,67 \%)$ & Sangat Baik \\
\hline
\end{tabular}

Berdasarkan tabel tersebut dapat dijelaskan bahwa, pertama, dari seluruh sampel yakni 60 butir soal, terdapat $46(76,67 \%)$ di antaranya yang memenuhi kriteria bahwa pilihan jawaban homogen dan logis dan ini berarti bahwa dari segi kriteria tersebut pada umunya soal termasuk dalam kategori baik. Kedua, dari seluruh sampel yakni 60 butir soal, terdapat $50(83,33 \%)$ di antaranya yang memenuhi kriteria bahwa soal mempunyai satu jawaban yang benar atau paling benar dan hal ini berarti bahwa dari segi kriteria tersebut pada umunya soal termasuk dalam sangat baik. Ketiga, dari seluruh sampel yakni 60 butir soal, terdapat 51 (85\%) di antaranya yang memenuhi kriteria bahwa pokok soal dirumuskan secara jelas dan logis dan hal ini berarti bahwa dari segi kriteria tersebut pada umunya soal termasuk dalam kategori sangat baik. Rata-rata nilai soal dari segi aspek materi ini adalah $81,67 \%$ yang berarti termasuk dalam kategori sangat baik.

Terdapat soal-soal yang mempunyai lebih dari satu, misalnya dua istilah yang sama artinya, misalnya gaya representatif dan figuratif atau tekstur dan rabaan bidang. Contoh lainnya jawaban yang sama-sama dapat menjadi jawaban, yaitu menanyakan cara membuat patung dengan tanah liat, dengan jawaban butsir dan modeling yang sama-sama benarnya. Mengenai pilihan jawaban yang tidak homogen dan logis, diketahui bahwa pada umumnya pilihan jawaban yang tidak relevan atau tidak dikenal. Beberapa kesalahan di antaranya: (1) media kayu sebagai untuk pilihan media menggambar, (2) istilah disposisi untuk kaidah komposisi, dan (3) istilah "asentral" dan "non simetris" yang tidak dikenal dalam konsep prinsip komposisi.

\section{b. Kualitas Soal dari Aspek Konstruksi}

Analisis dari segi konstruksi di sini meliputi delapan kriteria: (1) Pokok soal/ pilihan jawaban merupakan pernyataan yang diperlukan saja; (2) Pokok soal tidak memberi petunjuk ke arah jawaban benar; (3) Pokok soal tidak mengandung pernyataan negatif ganda; (4) Panjang pilihan jawaban relatif sama; (5) Pilihan jawaban bukan pernyataan "Semua pilihan jawaban di atas salah" atau "Semua pilihan jawaban di atas benar"; (6) Pilihan jawaban berupa angka disusun berdasarkan urutan besar kecil/ kronologisnya; (7) Gambar/grafik/tabel/ diagram/sejenisnya pada soal harus jelas dan berfungsi; (8) Butir soal tidak bergantung pada jawaban soal sebelumnya. Pada aspek konstruksi ini terdapat kriteria nomor 6 dan 7 yang hanya berlaku untuk soal tertentu yakni soal yang menggunakan gambar/grafik/tabel/diagram/sejenisnya,sehingga persentase jumlah bergantung pada jumlah soal yang menggunakan unsur tersebut. Rangkuman hasil analisis kualitas soal dari segi konstruksi dapat dilihat pada Tabel 3.

Berdasarkan tabel tersebut dapat dijelaskan bahwa, pertama, dari seluruh sampel yakni 60 butir soal, terdapat $50(83,33 \%)$ di antaranya yang memenuhi kriteria bahwa pokok soal dan/atau pilihan jawaban merupakan pernyataan yang diperlukan saja dan hal ini berarti bahwa dari segi kriteria tersebut pada umunya soal termasuk dalam kategori 
sangat baik. Kedua, dari seluruh sampel yakni 60 butir soal, terdapat $54(90,00 \%)$ di antaranya yang memenuhi kriteria bahwa pokok soal tidak memberi petunjuk ke arah jawaban benar dan hal ini berarti bahwa dari segi kriteria tersebut pada umunya soal termasuk dalam kategori sangat baik. Ketiga, dari segi seluruh sampel yakni 60 butir soal, terdapat $60(100,00 \%)$ atau seluruhnya memenuhi kriteria bahwa pokok soal tidak mengandung pernyataan negatif ganda dan hal ini berarti bahwa dari kriteria tersebut pada umunya soal termasuk dalam kategori sangat baik. Keempat, dari seluruh sampel yakni 60 butir soal, terdapat $59(98,33 \%)$ di antaranya yang memenuhi kriteria bahwa panjang pilihan jawaban relatif sama dan hal ini berarti bahwa dari segi kriteria tersebut pada umunya soal termasuk dalam kategori sangat baik. Kelima, dari seluruh sampel yakni 60 butir soal, terdapat $60(100,00 \%)$ atau seluruhnya memenuhi kriteria bahwa pilihan jawaban bukan pernyataan "Semua pilihan jawaban di atas salah" atau "Semua pilihan jawaban di atas benar" dan hal ini berarti bahwa dari segi kriteria tersebut pada umunya soal termasuk dalam kategori sangat baik. Keenam, dari 60 butir hanya 2 dua butir soal yang mengandung pilihan yang bersifat tingkatan dan 1 (50\%) butir di antaranya tidak memenuhi kriteria bahwa pilihan jawaban berupa angka disusun berdasarkan urutan besar kecil/kronologisnya dan hal ini berarti bahwa soal dalam kategori kurang baik. Ketujuh, dari 60 butir 22 soal yang menggunakan gambar ilustrasi dan $15(68,18 \%)$ butir di antaranya memenuhi kriteria bahwa gambar, grafik, tabel, diagram, atau sejenisnya pada soal harus jelas dan berfungsi, sehingga penggunaan gambar di sini termasuk dalam kategori baik. Kedelapan, dari seluruh sampel yakni 60 butir soal, terdapat $60(100,00 \%)$ atau seluruhnya memenuhi kriteria bahwa butir soal tidak bergantung pada jawaban soal sebelumnya dan hal ini berarti bahwa dari segi kriteria tersebut pada umunya soal termasuk dalam kategori sangat baik. Rata-rata nilai soal dari segi aspek konstruksi ini adalah $86,23 \%$ yang berarti termasuk dalam kategori sangat baik.

\section{Tabel 3. Hasil Analisis Soal dari Aspek Konstruksi}

\begin{tabular}{|c|c|c|c|c|}
\hline No. & Kriteria & Jumlah & Persentase & Nilai \\
\hline 1 & $\begin{array}{l}\text { Pokok soal/ pilihan jawaban merupakan pernyataan yang } \\
\text { diperlukan saja }\end{array}$ & 50 & $83,33 \%$ & Sangat Baik \\
\hline 2 & Pokok soal tidak memberi petunjuk ke arah jawaban benar & 54 & $90,00 \%$ & Sangat Baik \\
\hline 3 & Pokok soal tidak mengandung pernyataan negatif ganda & 60 & $100,00 \%$ & Sangat Baik \\
\hline 4 & Panjang pilihan jawaban relatif sama & 59 & $98,33 \%$ & Sangat Baik \\
\hline 5 & $\begin{array}{l}\text { Pilihan jawaban bukan pernyataan "Semua pilihan jawaban } \\
\text { di atas salah" atau "Semua pilihan jawaban di atas benar" }\end{array}$ & 60 & $100,00 \%$ & Sangat Baik \\
\hline 6 & $\begin{array}{l}\text { Pilihan jawaban berupa angka disusun berdasarkan urutan } \\
\text { besar kecil/kronologisnya }\end{array}$ & 1 dari 2 & $50 \%$ & Kurang Baik \\
\hline 7 & $\begin{array}{l}\text { Gambar/grafik/tabel/ diagram/sejenisnya pada soal harus } \\
\text { jelas dan berfungsi }\end{array}$ & $\begin{array}{r}15 \text { dari } \\
22\end{array}$ & $68,18 \%$ & Baik \\
\hline \multirow[t]{3}{*}{8} & Butir soal tidak bergantung pada jawaban soal sebelumnya & 60 & $100,00 \%$ & Baik \\
\hline & Jumlah & & $689,84 \%$ & \\
\hline & Rata-Rata & & $86,23 \%$ & Sangat Baik \\
\hline
\end{tabular}


Terdapat pokok soal-pokok soal yang mengandung penjelasan pengertian atau penjelasan tambahan tentang materi yang ditanyakan pada soal, misalnya penjelasan pengertian komposisi asimetris untuk menanyakan jenis gambar menggunakan jenis komposisi asimetris atau menguraikan berbagai jenis warna dalam menanyatakan karakteristik satau atau beberapa jenis warna. Terdapat penggunaan gambar, diagram, dan tabel yang tidak ditampilkan dengan benar, jelas, dan sekedar berfungsi sebagai tambahan yang tidak sebenarnya diperlukan. Terdapat pilihan jawaban yang berupa peringkat yang tidak diurutkan. Selain itu, terdapat beberapa perumusan pokok soal yang tidak ditulis secara lazim: (1) menyajikan butir-butir alternatif jawaban, misalnya diawali dengan gambar dan butir-butir pertanyaan yang sebenarnya merupakan alternatif jawaban, (2) Pokok soal tidak ditulis sebagai isian singkat, misalnya "Berikut ini adalah beberapa teknik dalam membuat patung ...".

Terdapat petunjuk kepada pilihan jawaban benar, terutama berupa padanan istilah, misalnya kata "flora" pada pokok soal dan "tumbuh-tumbuhan" pada pilihan jawaban. Contoh lainnya menanyakan nama teknik menyemprotkan cat dengan pilihan jawaban kunci “teknik spray". Mengenai panjang pendeknya jawaban, terdapat soal dengan pilihan jawaban yang hanya terdiri dari atas satu atau dua kata, sedangkan jawaban lainnya terdiri dari atas empat kata atau lebih, misalnya: (a) Trubus, Tarmizi, S. Sudjojono dan Dullah; (b) Basuki Abdulah dan Pirngadi, (c) Abdulah Surio subroto, (d) Raden Saleh. Terdapat perumusan jawaban yang tidak urut dari segi tingkatannya, yaitu jenis pensil menurut kualitasnya yakni B, HB, B4, dan B8, sedangkan seharusnya $\mathrm{HB}, \mathrm{B}, \mathrm{B} 4$, dan B8.

Terdapat gambar-gambar yang tidak atau kurang berfungsi misalnya: (1) gambar yang tidak diperlukan karena fakta yang ditanyakan sudah jelas, misalnya patung Pancoran di Jakarta dan (2) gambar tidak sesuai dengan konsep, misalnya lukisan bangunan sebagai ilustrasi tentang lukisan konstruksionisme dan patung tangan sebagai ilustrasi patung torso, dan (3) menanyakan jenis gambar komik, tetapi teks di dalam balon dialog tidak terbaca.

c. Kualitas Soal dari Aspek Bahasa

Analisis dari segi bahasa di sini meliputi: (1) Soal menggunakan bahasa yang sesuai dengan kaidah bahasa Indonesia; (2) Soal menggunakan bahasa yang komunikatif; (3) Pilihan jawaban tidak mengulang kata atau frase yang bukan merupakan satu kesatuan pengertian. Rangkuman hasil analisis kualitas soal dari segi konstruksi dapat dilihat pada Tabel 4.

Tabel 4. Rangkuman Hasil Analisis Soal dari Aspek Bahasa

\begin{tabular}{clccc}
\hline No. & \multicolumn{1}{c}{ Kriteria } & Jumlah & Persentase & Nilai \\
\hline 1 & Soal menggunakan bahasa yang sesuai dengan kai- & 54 & $90,00 \%$ & Sangat Baik \\
& dah bahasa Indonesia. & & & \\
2 & Soal menggunakan bahasa yang komunikatif. & 57 & $95,00 \%$ & Sangat Baik \\
3 & Pilihan jawaban tidak mengulang kata atau frase & 56 & $93,33 \%$ & Sangat Baik \\
& yang bukan merupakan satu kesatuan pengertian. & & & \\
\hline & & Jumlah & $278,33 \%$ & \\
& & Rata-Rata & $(92,78 \%)$ & Sangat Baik \\
\hline
\end{tabular}


Berdasarkan tabel tersebut dapat dijelaskan bahwa, pertama, dari seluruh sampel yakni 60 butir soal, terdapat $54(90,00 \%)$ di antaranya yang memenuhi kriteria bahwa soal menggunakan bahasa yang sesuai dengan kaidah bahasa Indonesia dan hal ini berarti bahwa dari segi kriteria tersebut pada umunya soal termasuk dalam kategori sangat baik. Kedua, dari seluruh sampel yakni 60 butir soal, terdapat $54(90,00 \%)$ di antaranya yang memenuhi kriteria bahwa soal menggunakan bahasa yang komunikatif dan hal ini berarti bahwa dari segi kriteria tersebut pada umunya soal termasuk dalam kategori sangat baik. Ketiga, dari seluruh sampel yakni 60 butir soal, terdapat $56(93,33 \%)$ di antaranya yang memenuhi kriteria bahwa pilihan jawaban tidak mengulang kata atau frase yang bukan merupakan satu kesatuan pengertian dan hal ini berarti bahwa dari segi kriteria tersebut pada umunya soal termasuk dalam kategori sangat baik. Rata-rata nilai soal dari segi aspek konstruksi ini adalah 81,67\% yang berarti termasuk dalam kategori sangat baik.

Terdapat kesalahan dari segi kaidah bahasa Indonesia: (1) penggunaan koma untuk memisahkan dua kalimat yang seharusnya masing-masing berdiri sendiri, (2) penyebutan nama tanpa diawali huruf kapital, misalnya "pulau Bali", (3) penggunaan kata depan "di" yang disambung dengan nama tempat, (4) penggunaan huruf kapital pada kata yang bukan nama diri.

\section{d. Kualitas Soal dari Tingkat (Level) Pe- ngetahuan dan Tingkat Kesukaran}

Tingkat (level) pengetahuan dibedakan menjadi enam kategori berdasarkan taksonomi Bloom yang diperbarui, yaitu ingatan, pemahaman, aplikasi, analisis, evaluasi, dan kreasi. Tingkat adalah seberapa sukar suatu butir dijawab oleh peserta didik. Dalam hal ini tingkat kesukaran butir soal ditentukan berdasarkan judgment penilai yang dibedakan menjadi tiga kategori, yaitu mudah, se- dang, dan sukar. Rangkuman hasil analisis kualitas soal dari segi konstruksi dapat dilihat pada Tabel 5.

Berdasarkan tabel tersebut, dari segi tingkat kesukaran, dapat dijelaskan bahwa, pertama, dari 60 butir dari sampel soal hanya terdapat $2(3,33 \%)$ butir soal yang termasuk dalam kategori sukar, $26(43,33)$ butir soal termasuk dalam kategori sedang, dan 34 $(56,67 \%)$ termasuk dalam kategori mudah. Selanjutnya dari segi tingkat pengetahuan, dari 60 sampel soal $37(61,67 \%)$ butir di antaranya merupakan soal dengan tingkat pengetahuan ingatan, 23 (38,33\%) lainnya merupakan soal dengan tingkat pengetahuan pemahaman, dan tidak terdapat soal yang mencapai tingkat penerapan atau yang lebih tinggi.

Tabel 5. Rangkuman Hasil Analisis Soal dari Segi Tingkat Kesukaran dan Tingkat (Level) Pengetahuan

\begin{tabular}{llrr}
\hline \multicolumn{2}{c}{ Kriteria } & Jumlah & Persentase \\
\hline Tingkat & Sukar & 2 & $3,33 \%$ \\
kesukaran & Sedang & 26 & $43,33 \%$ \\
& Mudah & 34 & $56,67 \%$ \\
Tingkat & Ingatan & 37 & $61,67 \%$ \\
pengetahuan & Pemahaman & 23 & $38,33 \%$ \\
& Aplikasi & 0 & $0,00 \%$ \\
& Analisis & 0 & $0,00 \%$ \\
& Evaluasi & 0 & $0,00 \%$ \\
& Penciptaan & 0 & $0,00 \%$ \\
\hline
\end{tabular}

\section{Pembahasan}

Berdasarkan analis data, dapat diketahui bahwa baik dari aspek materi, konstruksi, maupun bahasa, soal pilihan ganda pada penilaian hasil belajar sumatif seni rupa yang dibuat oleh para guru SMP di Kabupaten Sleman termasuk dalam kategori nilai sangat baik $(81,67 \%, 86,23 \%$, dan 92,78\%). Namun demikian, sebagai alat ukur yang baik setiap soal seharusnya tidak mengandung kesalahan baik dari segi materi, konstruksi maupun ba- 
hasa. Dari segi materi, masih terdapat soalsoal yang masih memiliki kelemahan seperti pilihan jawaban yang tidak homogen dan logis, terdapat lebih dari satu jawaban yang benar, dan pokok soal yang tidak jelas dan tegas.

Dari segi konstruksi, masih terdapat soalsoal yang memiliki kelemahan seperti pokok soal yang mengandung materi yang tidak perlu, misalnya berupa penjelasan pengertian atau penjelasan tambahan tentang materi soal, memberikan petunjuk kepada pilihan jawaban benar, dan panjang pilihan jawaban yang tidak relatif sama. Penggunaan gambar, diagram, dan tabel merupakan bentuk pemberian stimulus kasus yang baik, tetapi seharusnya ditampilkan dengan benar, jelas, dan bukan hanya berfungsi sebagai tambahan yang tidak diperlukan. Penggunaan pilihan jawaban yang berupa angka atau peringkat sangat jarang digunakan pada soal seni rupa, tetapi penggunaannya perlu diurutkan. Dari seluruh sampel soal yang dibuat guru tersebut tidak terdapat kelemahan seperti pokok soal yang mengandung pernyataan negatif ganda dan pilihan jawaban yang bernunyi "Semua pilihan jawaban di atas salah" atau "Semua pilihan jawaban di atas benar".

Dari segi bahasa, terdapat kelemahan dalam penggunaan tata bahasa, misalnya pokok soal yang bukan merupakan pertanyaan isian dan penggunaan tanda koma untuk memisahkan dua kalimat yang seharusnya terpisah dan penggunaan kata depan "di" yang disambung dengan nama tempat. Dari segi ejaan, masih terdapat penggunaan huruf kapital untuk mengawali kata yang bukan nama diri dan kata asing yang tidak ditulis dengan huruf miring. Masih terdapat pengungkapan gagasan yang kurang komunikatif, misalnya penyajian tabel sebagai stimulus kasus yang isinya cukup kompleks, berupa perbandingan cakupan unsur dari beberapa konsep sekaligus. Masih terdapat redundance pada pilihan jawaban berupa pengulangan kata atau frase yang bukan merupakan satu kesatuan pengertian.

Temuan penelitian ini yang terkait dengan tingkat kesukaran menunjukkan bahwa pada umunya soal dalam kategori mudah dan sedang, dan hanya sangat sedikit soal yang mencapai tingkat kesukaran yang tinggi. Menurut Arifin (2009: 270) bahwa untuk memperoleh prestasi belajar yang baik, sebaiknya proporsi antara tingkat kesukaran soal tersebar secara normal: (1) sukar $25 \%$, soal sedang $50 \%$, mudah $25 \%$, (2) sukar $20 \%$, sedang $60 \%$, mudah $20 \%$, atau (3) sukar $15 \%$, sedang $70 \%$, mudah $15 \%$. Mengacu pendapat tersebut, dapat disimpulkan bahwa perangkat soal yang dibuat oleh para guru di SMP Kabupaten Sleman belum memenuhi proporsi yang ideal. Terkait dengan tingkat (level) pengetahuan berdasarkan taksonomi Bloom yang diperbarui, soal-soal tersebut baru berkisar antara tingkat ingatan dan pemahaman, sehingga belum mencapai kriteria high order thinking skills (HOTS) yang diidealkan dalam penilaian hasil belajar dalam Kurikulum 2013.

\section{KESIMPULAN}

Penilaian sumatif hasil belajar seni rupa pada aspek mata pelajaran Seni Budaya SMP di Kabupaten Sleman dilaksanakan sesuai dengan acuan-acuan dalam Kurikulum 2013, dan disesuaikan dengan kebijakan sekolah dalam penjadwalan dan intake peserta didik yang ditetapkan oleh guru. Soal penilaian sumatif tersebut mencakup berbagai kategori pengetahuan dan dikembangkan dengan mengacu pada langkah-langkah penulisan yang sistematik. Instrumen penilaian sumatif yang utama adalah soal pilihan ganda dengan empat alternatif pilihan.

Instrumen utama yang diterapkan untuk penilaian sumatif hasil belajar seni rupa adalah soal pilihan ganda. Soal pilihan ganda yang dibuat oleh guru SMP di Kabupaten Sleman tersebut termasuk dalam kategori ni- 
lai sangat baik, baik dari aspek materi, konstruksi, maupun bahasa, $(81,67 \%, 86,23 \%$, dan $92,78 \%$ ). Namun demikian, dari segi materi, masih terdapat soal-soal yang masih memiliki kelemahan jika dibandingkan dengan kriteria penulisan soal yang baik. Paket soal untuk penilaian sumatif tersebut masih belum ideal dari segi proporsi dari tingkat kesukaran dan belum mencapai tingkat pengetahuan high order thinking skills.

Mengingat masih adanya beberapa kelemahan terutama dalam pembuatan soal pilihan ganda sebagai instrumen penilaian sumatif, disarankan kepada kelompok MGMP Seni Budaya untuk meningkatkan kompetensinya dalam mengembangkan soal pilihan ganda dengan melalui kegiatan analisis dan pengembangan soal secara bersama-sama dengan narasumber dari perguruan tinggi yang menguasai penilaian hasil belajar, serta bekerja sama dalam mengembangkan instrumen penilaian hasil belajar sumatif seni rupa untuk PTS, PAS, dan PAT.

\section{CREDIT}

Penelitian ini didukung oleh Universitas Negeri Yogyakarta melalui program Research Group.

\section{DAFTAR PUSTAKA}

Anderson, L.W., dan Krathwohl, D.R. 2001. A Taxonomy for Learning, Teaching, and Assesing: A Revision of Bloom's Taxonomy of Educatioanl Objectives. New York: Addison Wesley Longman, Inc.

Bauer, S. C. 2000. Should achievement test be used to judge school quality? Education Policy Analysis Archives, 46, 1-18.
Gronlund, N. E. 1982 Constructing achievement test. (3rd ed). New York: Prentice Hall, Inc., Englewood Cliffs.

Kementerian Pendidikan dan Kebudayaan. 2016. Kompetensi Inti dan Kompetensi Dasar Sekolah Menengah Pertama / Madrasah Tsanawiyah (SMP/MTs): Mata Pelajaran Seni Budaya. Kemendikbud: Jakarta.

Kementerian Pendidikan dan Kebudayaan. 2017. Panduan Penilaian oleh Pendidik dan Satuan Pendidikan Sekolah Menengah Pertama. Direktorat Pembinaan Sekolah Menengah Pertama : Jakarta.

Murwani, S. 2006. Evaluasi pendidikan: suatu pengantar dalam evaluasi pendidikan: Konsep dan aplikasi. Jakarta: Uhamka Press.

Nurung, M. 2008. Kualitas Tes Ujian Akhir Sekolah Berstandar Nasional (UASBN) IPA SD Tahun Pelajaran 2007/2008 Di Kota Kendari. Tesis. UNY: Yogyakarta. Santoyo, S.W., Harini, N. \& Zandra, R. A. 2019. Pembelajaran Karawitan Pada Kegiatan Ekstrakurikuler. Imaji, 17(2), 171-178.

Suharsimi, A. 2009. Dasar-Dasar Evaluasi Pendidikan. Jakarta: Bumi Aksara.

Thorndike, R. M. 2005. Measurement and evaluation in psychology and education (7th ed). New Jersey: Pearson Education, Inc.

Widyaningsih, S. W. \& Yusuf, I. 2018. Analisis Soal Modul Laboratorium Fisika Sekolah I Menggunakan Racsh Model, Gravity: Jurnal Ilmiah Penelitian dan Pembelajaran Fisika, 4(1), 33-46. 